\title{
Localization and characterization of acid phosphatase activity in Bonamia ostreae (Ascetospora), an intrahemocytic protozoan parasite of the flat oyster Ostrea edulis (Bivalvia)
}

\author{
D. Hervio, D. Chagot, P. Godin, H. Grizel, E. Mialhe \\ IFREMER, Laboratoire de Biologie et d'Ecologie des Invertébrés Marins, Unité de Recherche en Pathologie, Immunologie et \\ Génétique Moléculaire, BP 133, F-17390 La Tremblade, France
}

\begin{abstract}
Acid phosphatase activity was cytochemically detected at the ultrastructural level in the protozoan Bonamia ostreae, an intrahemocytic parasite of the flat oyster Ostrea edulis. Lead nitrate was used as capture agent for phosphate liberated during the hydrolysis of the substrate (cytidine $5^{\prime}$ monophosphate). Lead phosphate precipitation, indicative of enzyme activity, was located in membrane-bound organelles corresponding to the cytoplasmic inclusions known as 'dense bodies' Acid phosphatase activity level and sodium L-tartrate inhibition were measured spectrophotometrically from a purified parasite suspension. The possible involvement of this enzyme in intracellular survival of $B$. ostreae is discussed.
\end{abstract}

\section{INTRODUCTION}

The parasitic protozoan Bonamia ostreae is the etiological agent of bonamiasis, or hemocytic disease, of the flat oyster Ostrea edulis (Bivalvia). It multiplies within a parasitophorous vacuole inside the hemocytes of its host. Most studies concerning defense reactions in molluscs assign a role of prime importance to hemocytes (Cheng 1981, Sminia \& Van Der Knaap 1987). These cells carry out phagocytic activities and possess enzymes involved in superoxide-dependent killing and intracellular degradation. These characteristics are similar to those of vertebrate macrophages. Thus, $B$. ostreae-hemocyte interactions may be compared to parasite-macrophage interactions known in human and veterinary parasitology for protozoans such as Leishmania, Trypanosoma or Toxoplasma. Research done on parasitization of mammalian macrophages by such parasites has demonstrated the existence of several adaptive mechanisms for survival in an immunocompetent cell (Edelson 1982, Mauël 1984, Alexander \& Russel 1985, Zingales \& Colli 1985). Among others, promastigote acid phosphatase, described by Gottlieb \& Dwyer (1981a) and isolated by Glew et al. (1982) from Leishmania donovani, is cap- able of inhibiting the production of superoxide anions by human neutrophils. These findings provided a possible explanation for how the intracellular parasite escapes inactivation by the host cell (Remaley et al. 1984).

In the present study, we report the localization and characterization of acid phosphatase activity in the intrahemocytic parasite Bonamia ostreae.

\section{MATERIALS AND METHODS}

Parasites. Purified parasitic cell suspensions were obtained from parasitized flat oyster tissues, according to the protocol of Mialhe et al. (1988). Parasites were counted using a hemocytometer Malassez cell at $200 \times$ magnification.

Cytochemistry. Parasite suspensions in filtered seawater were fixed by brief exposure to $2 \%$ glutaraldehyde solution (v/v) buffered with $0.1 \mathrm{M}$ sodium cacodylate- $\mathrm{HCl}, \mathrm{pH} 7.4\left(1 \mathrm{~h}\right.$ at $\left.4{ }^{\circ} \mathrm{C}\right)$, then rinsed 3 times in cacodylate buffer. Osmolarity of all solutions was adjusted to $1000 \mathrm{mOsmol}$ with sucrose.

For light microscopic detection of acid phosphatase activity, the azo dye staining method of Barka \& Ander- 
son (1963) was used. Parasites were incubated $1 \mathrm{~h}$ at $37^{\circ} \mathrm{C}$ in a Bonamia ostreae/acid phosphatase activity medium containing $20 \%$ sucrose (naphtol AS.MX phosphate, disodium salt, $40 \mathrm{mg}$; N.N dimethyl formamide, $4 \mathrm{mI} ; 0.2 \mathrm{M}$ acetic acid-sodium acetate buffer, $\mathrm{pH}$ $5.0,20 \mathrm{ml}$; distilled water, $48 \mathrm{ml}$ ), to which was added a mixture of $3.2 \mathrm{ml}$ of $4 \%$ pararosanilin and $3.2 \mathrm{ml}$ of $4 \%$ sodium nitrite. The $\mathrm{pH}$ was adjusted to 5.0.

For electron microscopic detection, the fixed parasitic suspensions were incubated for $1 \mathrm{~h} 30 \mathrm{~min}$ at $37^{\circ} \mathrm{C}$ in Novikoff's medium (1963) containing $20 \%$ sucrose and formulated as follows: cytidine 5 'monophosphate, $25 \mathrm{mg}$; distilled water, $12 \mathrm{ml} ; 0.05 \mathrm{M}$ acetate buffer, $\mathrm{pH}$ $5.0,10 \mathrm{ml} ; 1 \%$ lead nitrate, $3 \mathrm{ml}$. Cells were rinsed in $0.05 \mathrm{M}$ acetate buffer-sucrose, then in $0.1 \mathrm{M}$ cacodylate buffer, and post-fixed with $1 \%$ osmium tetraoxide for 30 min, immobilized in agarose, dehydrated and embedded in Epon 812. Ultrathin sections were obtained and observed without staining, using a Jeol 1200 CX electron microscope.

Colorimetric determination of acid phosphatase activity. For colorimetric determination, the homogenate from a purified parasite suspension was used as a crude preparation of acid phosphatase. This suspension, containing ca $100 \times 10^{6}$ parasites $\mathrm{ml}^{-1}$, was frozen and thawed. It was incubated for $1 \mathrm{~h}$ at $37^{\circ} \mathrm{C}$ in $0.2 \mathrm{M}$ citrate buffer at $\mathrm{pH} 4.9$, and $10 \mathrm{mM}$ disodium phenylphosphate in a final volume of $1 \mathrm{ml}$, then mixed and incubated for $10 \mathrm{~min}$ in the dark in a solution containing $30 \mathrm{mM}$ amino-4-antipyrine, $120 \mathrm{mM}$ sodium arsenate $(1 \mathrm{ml})$, and $75 \mathrm{mM}$ potassium ferricyanide $(1 \mathrm{ml})$.
Total acid phosphatase activity was determined according to the following reaction:

$$
\text { Phenylphosphate } \stackrel{\begin{array}{c}
\text { acid } \\
\text { phosphatase }
\end{array}}{\mathrm{pH} 4.9} \text { phenol + phosphate }
$$

The phenol liberated was measured in the presence of reagents of the solution previously described. Sodium arsenate stopped the enzymatic reaction. After incubation, the amount of phenol liberated was determined spectrophotometrically at $510 \mathrm{~nm}$. Resulting acid phosphatase activity units were expressed as nanomoles of phenol produced per minute per $10^{6}$ cells.

The inhibition of this activity was also measured after adding $0.05 \mathrm{ml} 1 \mathrm{M}$ sodium L-tartrate to a sample before its incubation for $1 \mathrm{~h}$ at $37^{\circ} \mathrm{C}$.

\section{RESULTS}

\section{Cytochemistry}

Light microscopic examination of purified parasitic suspensions incubated in naphtol AS.MX as substrate and diazotized pararosanilin as coupling agent for the enzymatically liberated naphtol led to the appearance of a brownish reaction product condensed in a relatively large granule.

At the ultrastructural level, electron-dense deposits of lead phosphate, indicative of acid phosphatase activity, were found in membrane-bound organelles (Fig. 1)

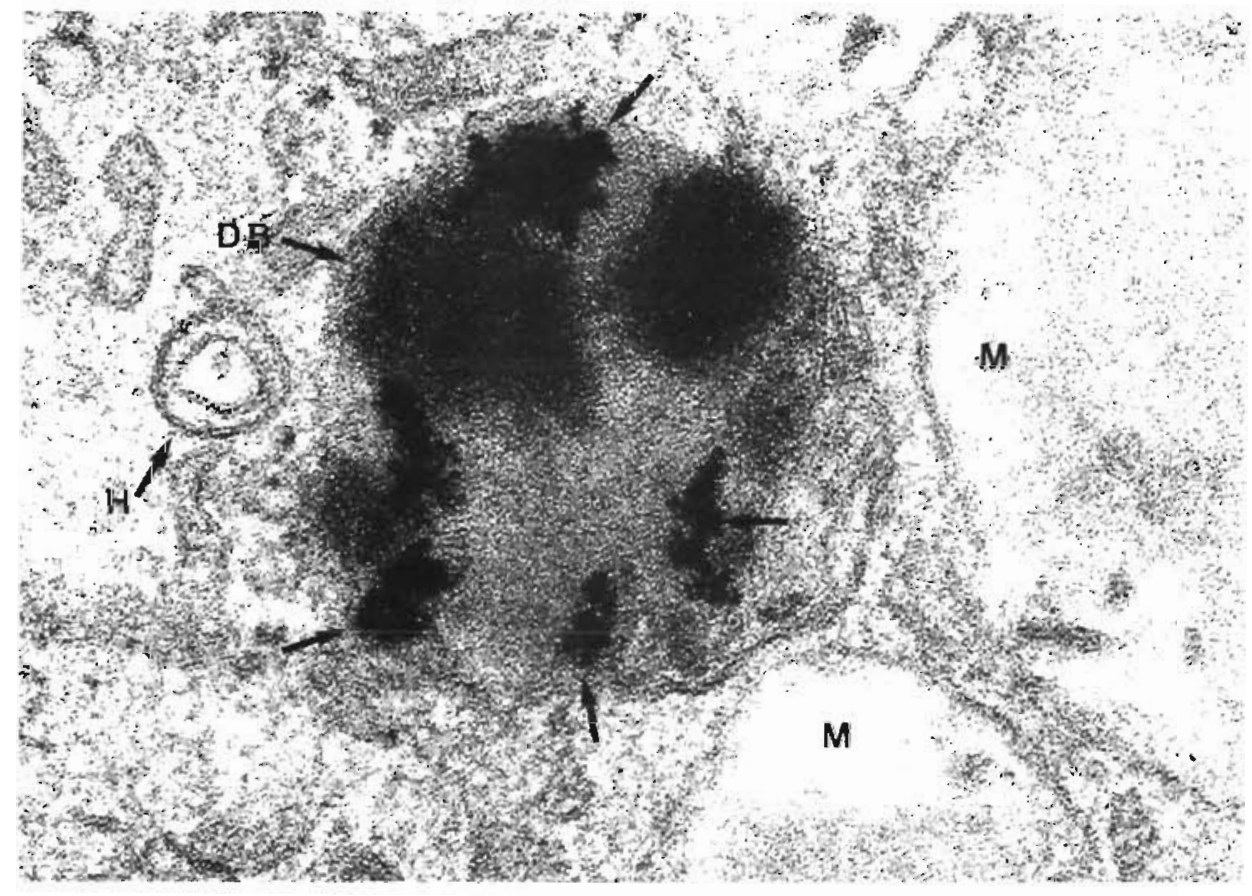

Fig. 1. Bonamia ostreae. Electron micrograph showing lead precipitation (arrows) occurring in 'dense bodies' (DB) in the presence of acid phosphatase. $\mathrm{H}$ : haplosporosome; $\mathrm{M}$ : mitochondria. $(150000 \times)$ 
corresponding to the spherical, more or less electrondense cytoplasmic inclusions known as 'dense bodies' when observed using morphological techniques (Fig. 2). No lead phosphate precipitation occurred in mitochondria or haplosporosomes. No reaction product could be demonstrated to be associated with the plasma membrane of the parasite. No deposition was seen when the parasites were incubated in a medium lacking substrate.

\section{Spectrophotometric analysis}

Acid phosphatase activity of frozen and thawed Bonamia ostreae, as determined by colorimetric assay, was evaluated at $2 \times 10^{2} \mathrm{nmol} \mathrm{min}{ }^{-1}$ per $10^{6}$ cells. Use of $1 \mathrm{M}$ sodium L-tartrate in the incubating medium strongly inhibited this activity. Inhibition was determined to be $87 \%$

\section{DISCUSSION}

This evidence of acid phosphatase activity in Bonamia ostreae is new among the Ascetospora. Cytochemical localization of this activity in the 'dense bodies' raises questions concerning the role of these organelles and their development. Although this enzyme is considered as a lysosome-marker, it has an extralysosomal distribution in several tissues. Additional hydrolytic enzymatic activities should be demonstrated in the 'dense bodies' before considering them to be lysosome-like. The intracellular distribution, restricted to the dense granules, limits our understanding of the origin of the acid phosphatase, site of glycosylation and intracellular delivery pathways. Such a location makes it difficult to understand the possible role of Bonamia ostreae acid phosphatase in disease pathogenesis when compared with leishmanial activities. In these trypanosomatids, acid phosphatase is secreted or shed extracellularly (Lovelace et al. 1986), or less frequently, is distributed on the surface of cells and located on the external side of membranes (Gottlieb \& Dwyer 1981b). It has been proposed that the membrane-bound acid phosphatase of Leishmania donovani alters the host's cell function, based on the observation of diminished superoxide production by macrophages incubated with enzyme purified from the parasite (Remaley et al. 1984). This might indicate a contribution of acid phosphatase to survival of the parasite by interfering with host oxygen-dependent killing mechanisms. In spite of a different distribution pattern of acid phosphatase activity in $B$. ostreae, spectrophotometric determination indicated that the level of this activity is equivalent to levels found in several Leishmania species (Lovelace \& Gottlieb 1986). As in most Leishmania species, the acid phosphatase activity in $B$. ostreae is highly sensitive to inhibition by sodium L-tartrate (Lovelace \& Gottlieb 1986). Interference of $B$. ostreae with production of

Fig. 2. Bonamia ostreae infecting Ostrea edulis. Ultrathin section of naturally infected oyster hemocyte, after double staining with aqueous solutions of lead citrate and uranyl acetate. Hem: hemocyte; Par parasite; DB: dense body $(38000 \times)$

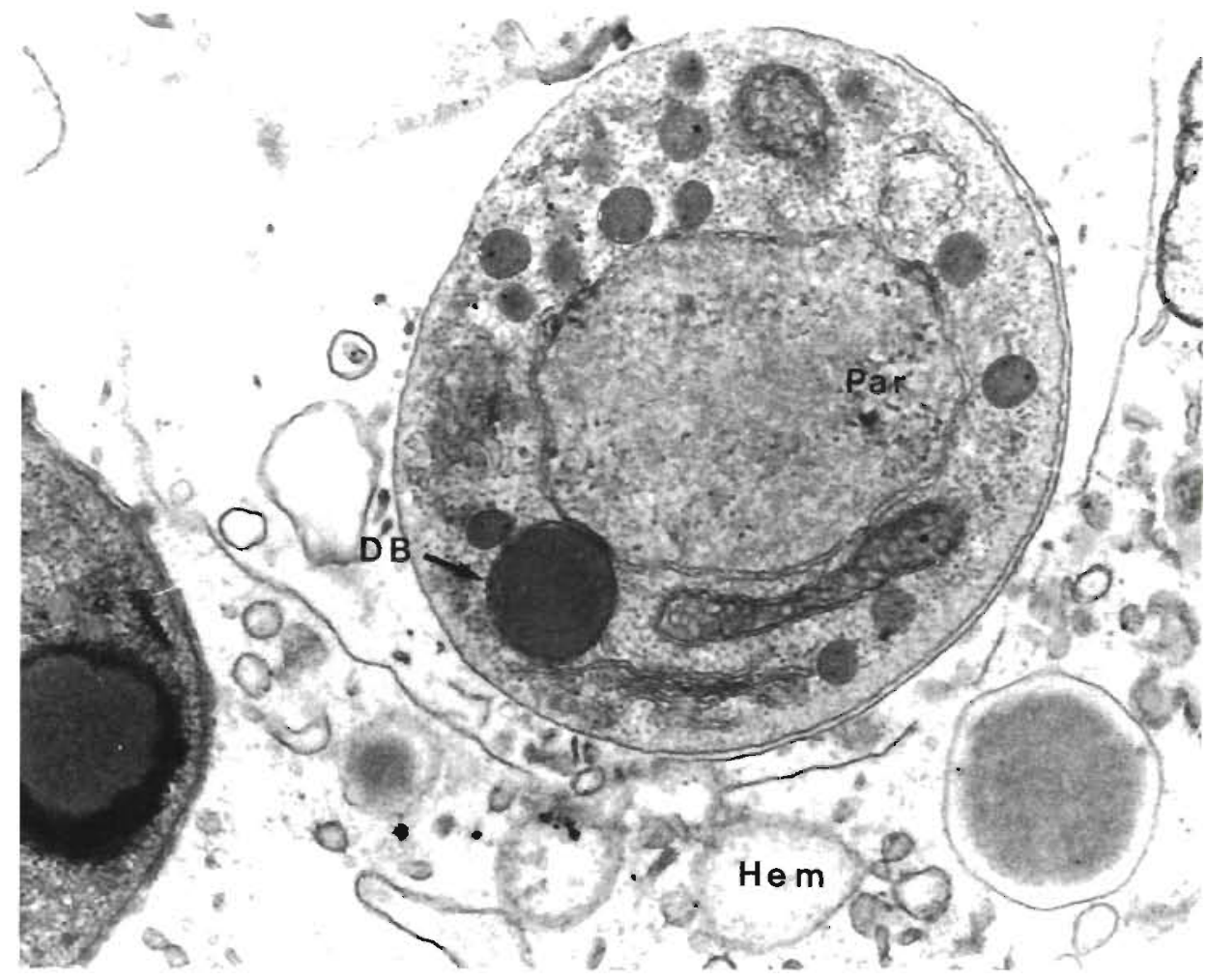


toxic free oxygen radicals by hemocytes has been demonstrated (Hervio et al. 1988, Jean-Chagot 1989). The acid phosphatase activity in $B$. ostreae needs to be analyzed in order to clarify its biological role. Inhibition of hemocytic superoxide anion production by purified enzyme should be measured in a superoxidedismutase-inhibitable cytochrome $\mathrm{c}$ reduction assay. Many important cellular processes other than phagocytic events are controlled by phosphorylationdephosphorylation of proteins.

Understanding of the physiologic and physiopathologic properties of Bonamia ostreae acid phosphatase might allow a better knowledge not only about the particular hemocyte-parasite interplay, but also about parasite-associated phosphatase modifications of host cell metabolism in general. Finally, based on information acquired for vertebrate macrophage parasites, it will be necessary to look for other parasitic components like catalase and peroxidase which might be involved in host-parasite relationships.

\section{LITERATURE CITED}

Alexander, J., Russel, D. G. (1985). Parasite antigens, their role in protection, diagnosis and escape: the leishmaniases. Curr. Topics Microbiol. Immunol. 120: 43-67

Barka, T., Anderson, P. (1963). Histochemistry: theory, practice and bibliography. New York, Harper and Row

Cheng, T. C. (1981). Bivalves. In: Ratcliffe, N. A., Rowley, A. F. (eds.) Invertebrate blood cells. Academic Press, London, p. 233-300

Edelson, P. J. (1982). Intracellular parasites and phagocytic cells. Cell biology and pathophysiology. Rev. infect. Dis. 4(1): $124-135$

Glew, R. H. Czuczman, M. S., Diven, W. F., Berens, R. L., Pope, M. T., Katsoulis, D. E. (1982). Partial purification and characterization of particulate acid phosphatase of Leish-

Responsible Subject Editor: A. K. Sparks, Seattle, Washington, USA mania donovani promastigotes. Comp. Biochem. Physiol 72B: $29-42$

Gottlieb, M., Dwyer, D. M. (1981a). Leishmania donovani surface membrane acid phosphatase activity of promastigotes. Expl. Parasit. 52: 117-128

Gottlieb, M., Dwyer, D. M. (1981b). Leishmania donovani, protozoan parasite of humans: surface membrane with externally disposed acid phosphatase. Science 212: 939-941

Hervio, D., Bachère, E., Mialhe, E., Grizel, H. (1988). Chemiluminescent responses of Ostrea edulis and Crassostrea gigas hemocytes to Bonamia ostreae (Ascetospora). Devl. comp. Immun. 13(4): 449

Jean-Chagot, D. (1989). Caractérisation morphologique et fonctionnelle des hémocytes d'Ostrea edulis et de Crassostrea gigas, Mollusques Bivalves. Etude in vitro de leurs interactions avec le protozoaire Bonamia ostreae (Ascetospora). Thèse, Ecole Pratique des Hautes Etudes, Université de Montpellier

Lovelace, J. K., Dwyer, D. M., Gottlieb, M. (1986). Purification and characterization of the extracellular acid phosphatase of Leishmania donovani. Molec. Biochem. Parasit. 20: $243-251$

Lovelace, J K., Gottlieb, M. (1986). Comparison of extracellular acid phosphatase from various isolates of Leishmania. Am. J. trop. Med. Hyg. 35 (6): 1121-1128

Mauël, J. (1984). Mechanisms of survival of protozoan parasites in mononuclear phagocytes. Parasitology 88: 579-592

Mialhe, E., Bachère, E., Chagot, D., Grizel, H. (1988). Isolation and purification of the protozoan Bonamia ostreae (Pichot et al. 1980), a parasite affecting the flat oyster Ostrea edulis L. Aquaculture 71: 293-299

Novikoff, A, B. (1963). Lysosomes in the physiology and pathology of cells: contribution of staining methods. In: Renck, Cameron (eds.) Ciba Found. Symp. Lysosomes. J. A. Churchill, London, p. 36-77

Remaley, A. T., Kuhns, D. B., Basford, R. E., Glew, R. H., Kaplan, S. S. (1984). Leishmanial phosphatase blocks neutrophil $\mathrm{O}_{2}$-production. J. biol. Chem. 259(18), 1173-1175

Sminia, T., Van Der Knaap, W. P. W. (1987). Cells and molecules in molluscan immunology. Devl. comp. Immun. 11: 17-28

Zingales, B., Colli, W. (1985). Trypanosoma cruzi: interaction with host cells. Curr. Topics Microbiol. Immunol. 117: $129-152$

Manuscript first received: December 28, 1990

Revised version accepted: July 22, 1991 